\title{
NORDIC COOPERATION WITHIN THE FIELD OF COMPUTING
}

\author{
Erik Bruhn \\ Cofounder of Danish Data Society and Nordic Data Union - Chiefeditor of the nordic \\ magasin DATA-administrator of BIT 1970-2002; ebru@ddf.dk
}

\begin{abstract}
Already in 1959, active users started the Nordic co-operation organizing the first joint symposium in the use of computers with 270 participants. The cooperation enlarged rapidly and developed into well-organized forms. This paper concentrates on the cooperation between the Nordic user federations and especially on the joint journal projects, DATA, and BIT.
\end{abstract}

Key words: Nordic computers - NordDATA - BIT

\section{INTRODUCTION}

In 1948, the Swedish government established an organization called "Matematikmaskinnämnden" that would investigate the possibilities for building a number-machine (mathematics-machine) in Sweden. One of the leading people in that committee was Professor Carl-Erik Fröberg, who for the last fifty years has influenced the computing society, especially in the Nordic countries.

The first machine was ready in February 1950 and had its inauguration in April in Stockholm. They named the machine BARK and it was a 32-bit machine capable of performing an addition operation in $150 \mathrm{~ms}$ and a multiplication operation in $250 \mathrm{~ms}$. BARK consisted of 5,000 telephonerelays.

Work continued to improve BARK and one person meant very much in that connection - Erik Stemme - who after a study tour to the USA headed the work leading to the building of BESK (Binär Elektronisk Sekvens 
Kalkylator). With a 40-bit machine, it was now possible to perform an addition operation in $56 \mu$ s and a multiplication in $350 \mu \mathrm{s}$. The memorycapacity was 512 words. The length of instruction was 20 bits and thus every word could contain two instructions. BESK was ready in 1953.

When BESK was build, Finns, Norwegians, and Danes started looking at what was going on in Sweden. They wanted to have a machine as well. Thomas Hysing was heading a project under "Utvalget for Matematikkmaskiner", that lead to the building of NUSSE (Norsk Universal Siffermaskin Selvstyrt Elektronisk). NUSSE was ready end 1954.

From 1954 to 1960, Finland developed and built ESKO (Elektronisk Serie-KOmputator) through the governmental organization "Matematikmaskinkommision" headed by the well-known mathematician Rolf Nevanlinnas. Together with university rector P.J. Myrberg, the role of Professor Nevanlinnas in that connection was considerable. Hans Andersin and Tage Carlsson headed the actual work. Unlike other Nordic initiatives from that period, ESKO did not use the BESK design; rather, they based it on the German machine G1 a from Göttingen. That machine was not ready, though, and it took much more time and money to get ESKO ready than originally planned. When ESKO was finally ready, the general development had gone a much further. The primary function of ESKO ended up being educating pioneers within the computing field.

Denmark was the last of the Nordic countries to get started. The Danes followed the work with BESK closely but did not have enough resources of their own to get started before end 1955, when "Regnecentralen" (Dansk Institut for Matematikmaskiner) was established under the management of "Akademiet for de tekniske Videnskaber" and started building DASK.

The building and use of computers in the four Nordic countries brought constructors and scientists together and a need for exchange of experience emerged. Again, "Matematikmaskinnämnden" took the initiative by an invitation to a "Nordisk Symposium over Använding av Matematikmaskiner" (NordSAM) in Karlskrona together with "Kungl. Orlogsmannasälskabet". Soon a need for Nordic cooperation emerged and again the Norwegians took the initiative by inviting representatives from all the four Nordic computer societies. Ironically enough the information societies were not invited and the continuation of NordSAM became one of the three "important legs" that built upon the Nordic cooperation; the two others were the publications of magazines and the Nordic conferences (NordDATA). 


\section{NORDDATA}

NordDATA soon became a great success and continued to exist until 1995. Through the years, NordDATA contributed considerably to the economic wellbeing of the Nordic computer societies by producing a good profit to every society every four years. The number of participants kept raising and in 1985 NordDATA had 2,450 participants. A long array of politicians and international experts contributed. One of those in the 1970 s and 80 s was Phil Dorn, who was a permanent writer in DATA.

NordDATA usually took place in June and therefore the conference gave many participants a good opportunity to see new places in the Nordic countries - even outside their capitals. The conference venues included places as Tammerfors, Åbo, Göteborg, Stavanger, Bergen, and Trondheim. The many participants who often brought their spouses and the guests often marked the city.

NordDATA did not take place in 1974 because the Swedish societies had accepted to arrange the IFIP Congress in Stockholm - with great success and nice weather. During the conference DATA, which had started in 1971, did a publication every day bringing news from the conference, interviews with the many international experts, and tips on tourism around Stockholm.

One specific peace of news was especially interesting. DATA was the first news media in Europe to inform us about Nixon resigning as president of the USA. We were working with dataCONGRESSnews at 4 o'clock in the morning; during that time, we were listening to the radio. When hearing about Nixon resigning, a few pictures were eliminated go give place to this great peace of news. DATA had an editorial staff of twelve people especially put together for the occasion and Nordic IT-suppliers who paid for publishing it.

Many companies used NordDATA in the continued professional education of their employees. They were partly presented for "state of the art" technology presentations and NordDATA partly became the place were you got your thoughts confirmed or were given ideas as to how you could solve the problems you were facing. Moreover, off course NordDATA provided good opportunities for networking and thus getting worthwhile contact. Finally yet importantly many good friendships have started during NordDATA conferences.

The aim of the NDU seminars was to bring together data-professionals, politicians, scientists, and administrators to discuss the problems arising in the wake of the new technology emerging and thus contributing to reasonable laws and guidelines within the area. Many highly skilled participants often succeeded in getting relevant problems on the agenda and ensuring that discussions remained focused. 
Ten seminars had taken place in eight Nordic cities. The first one was "Persondata og integritet" (personal data and integrity) in 1975 in Oslo and it is probably the seminar that had the greatest impact. When the seminar took place, they had a law on data protection in Sweden and a similar law was being prepared in Denmark and Norway. The discussions taking place at the first NDU seminar in which amongst others all the members of the Danish Parliament committee on legal affairs participated. It did in fact influence these laws considerably. At the same time, contacts occurred between politicians, IT-professionals, and civil servants.

Another seminar on "Edb og skolepolitik" (IT and schools) took place in Reykjavik in 1983 and many of the influential school-people of the time participated. With certainty, they moved more than commas in the reports on school-policy written that winter. Other issues discussed were society's vulnerability, the need for a data policy, data policy and working life, datascience, development of technology, the conditions of people, freedom of speech, freedom of communication, IT and intellectual property rights, and data technology and culture.

\section{PUBLICATIONS OF JOURNALS}

The "third leg" was the publication of journals under the management of NDU. Amongst the Danes, Finns, and Norwegians they had already agreed in 1965 that this activity should have high priority. The Swedish society had an agreement with Sven Hed, who published "Automatisk Databehandling", after having closed the society's own journal, DATA. In January 1966, Denmark and Norway started to cooperate on publishing the Norwegian journal "Moderne Databehandling". The Finns considered it easier to read a Swedish journal than a Danish/Norwegian one and they therefore went into an agreement with Sven Hed as well.

During all meetings in NDU discussion ensued on the way to publish a common Nordic journal without considering any commercial interests. Actually, not allowing companies like IBM, Bull, and ICT to have too much influence in the Nordic computer societies was an important detail. They had their own user-groups where they could scamper about.

After the NDU general assembly in 1970, they established a committee consisting of Hans Rällfors (Sweden), Eivind Barca (Norway), Jussi Tuori (Finland), and me from Denmark. The committee looked into the possibilities of publishing a Nordic journal either by cooperating with an existing publishing house or by buying one. The committee soon decided that NDU should have its own journal, but also that professional publishing expertise should participate in the work herewith. The committee chose Lars 
Wickmann from Bonniers Affärsforlag; he was to contribute his broad knowledge from one of the biggest Nordic publishing houses and he was a great support as editor.

In December 1970, an extraordinary NDU general assembly meeting decided to establish a limited company with each of the Nordic societies contributing DKK 17,500 in share capital and Bonniers contributed DKK 30,000 . However, the societies bought Bonniers share in 1977. In this way, it was possible to establish a secretariat where the manager was to both promote Nordic cooperation and establish a common Nordic journal.

Publishing professionals did not give the new company any chance to survive because of a mix of articles, written in different languages. Nevertheless, it soon turned out that where there is a will, there is a way. I created a possibility for reading the neighbor-languages (Finnish not included). It may take a little more time, but as long as the information is valuable, it was all right.

The market for computer journals turned out to be profitable and our journal had good years, during which the societies did not have to contribute. We only had to pay the variable printing costs in connection with the group subscriptions. We paid the rest by selling ads.

The journal soon established contacts with the professionals and experts who were capable of influencing the development of thing both technically and society wise. In that way, the journal - together with the NDU seminars and NordDATA - definitely contributed to the use of computing in the Nordic countries being at a very high level and according to many, the highest in the world. This was probably also an effect of no one specific group having the ability to decide on developments. A long range of specialists, scientists, and opinion formers regularly had articles in DATA, like also international feature writers like Phil Dorn (USA) and Nancy Foy (UK).

When the market turned out to be profitable and the journal had good years, many other PC and computing journals and magazines became competitors. The competition became tough, but DATA ended up living for 18 years ending with a book "EDB historik - I nordisk perspektiv".

The Nordic cooperation had many good years with a permanent secretariat and regular meetings four times a year. I hope that the future will bring us someone who sees it as his or her mission to re-establish an effective and positive coordination of the Nordic society activities and have the Nordic cooperation flourish again. 


\section{BIT}

The earlier mentioned Nord SAM conference in Copenhagen in 1960 also was the beginning of the journal $B I T$, now in publication for 43 years. In the founding meeting, the participants included Bech and Fröberg (Sweden), Peter Naur (Denmark) Jan Garwick (Norway), and Olli Lokki (Finland). They agreed that the journal should contain articles on computer technology, numeric analysis, operational analysis, programming, and data processing.

From the beginning, it was crucial that articles in BIT should be on a very high professional level. Many international scientists have published their scientific articles in BIT and the journal has contributed to establishing contacts between Nordic and international scientific communities.

$B I T$ soon became a great success technically and with regard to the number of subscribers ( 688 subscribers after one year). BIT's finances were a problem, though. During the first ten years, we had to get support from a variety of organizations, especially "Regnecentralen" (Denmark), but also "Matematikmaskinnämnden" (Sverige) and "Norges Forskningsråd". Later on the Publishing Board supported BIT financially until 1983. In 1983, we saw a strong raise in income because of the fact that all subscribers outside the Nordic area received subscription rates in US dollars. The dollar started rising in 1983 and $B I T$ has been financially independent since then.

"Regnecentralen" was unable to host BIT in 1971 and we needed a new setup. Therefore, Svenska Samfundet för Informationsbehandling, Norsk Selskab for Elektronisk Informationsbehandling, Dansk Selskab for Datalogi, and Finska Dataföreningen founded Stiftelsen BIT with its own articles.

The close contact with NDU was natural, bearing in mind that the field of activity of BIT and the NDU members were identical. NDU had established a secretariat in Copenhagen that same year and it therefore was natural to place the administration of BIT in Copenhagen as well.

In 1993, a discussion came up on whether it was opportune to have "computer science" and "numerical mathematics" in the same journal. It ended up with a group of Finns starting a new journal called the Nordic Journal of Computing with Esko Ukkonen as its editor in chief.

At the same time, BIT changed its name to BIT Numerical Mathematics with Åke Björck as its editor in chief. Since the fields of activity of BIT and the NDU members were no longer identical, they decided in 2003 - in connection with a change of secretariat - to form a new foundation. According to the articles of the existing BIT foundation, this decision requires confirmation at two general assemblies. From 2004, the board of the new BIT foundation will consist of representatives from the four Nordic academies: DNVA, STA, ATV, and IVA. 
As of 2004, the Institut Mittag-Leffler, a Nordic science institute under the management of The Royal Swedish Academy of Sciences administers $B I T$. The institute works closely with universities in all the Nordic countries. Institut Mittag-Leffler also publishes Acta Metematica, one of the world's most well respected journals. I hope that BIT can benefit from that fact and thus expect a raise in the number of subscribers. BIT's good financial situation since the mid 1980s has made it possible to award several Carl-Erik Fröberg-prizes. Last year, the prize went to Stig Faltinsen from Oslo. 